Poznańskie Studia Teologiczne 28(2014), s. 255-267.

doi: $10.14746 /$ pst.2014.28.17

Jerzy Adamczyk

Wyższe Seminarium Duchowne w Radomiu

\title{
Formacja katechetów w aspekcie kanonicznym
}

Papież Paweł VI w adhortacji apostolskiej Evangelii nuntiandi pisał:

wszystkim pracownikom w ewangelizacji konieczne jest pieczołowite przygotowanie, a jak najbardziej potrzebują go ci, którzy oddają się posłudze Słowa. [...] Wszak wszyscy wiemy, że sztuka mówienia ma dzisiaj bardzo wielkie znaczenie i wagę. Jakżeżby więc kaznodzieje i katecheci mogli ją zaniedbać? Dlatego wyrażamy usilne życzenie, aby w każdym Kościele partykularnym Biskupi należycie dbali o wykształcenie wszystkich ministrów Słowa ${ }^{1}$.

Przytoczone słowa potwierdzają konieczność formacji katechetów, gdyż „każda działalność duszpasterska, która nie opiera się w swojej realizacji na osobach rzeczywiście uformowanych i przygotowanych, naraża na niebezpieczeństwo swoją jakość. Narzędzia pracy nie mogą być naprawdę skuteczne, jeśli nie będą używane przez dobrze uformowanych katechetów"'.

Przedmiotem naszego zainteresowania było zagadnienie odpowiedniego przygotowania nauczających katechezy z punktu widzenia kanonicznego. Najpierw zwrócono uwagę na konieczność formacji katechetów, z kolei została naświetlona kwestia podmiotów odpowiedzialnych za przygotowanie katechetów, wreszcie omówiono zagadnienie odnoszące się do charakteru i treści przygotowania katechetów, jak również szkół dla katechetów.

\section{Potrzeba formacji katechetów}

Każdy system pedagogiczny do dobrego kształcenia i wychowania wymaga dobrego nauczyciela-wychowawcy. Podobną rolę przypisuje się katechecie za-

\footnotetext{
${ }^{1}$ Paulus PP. VI, Adhortatio Apostolica, De evangelizatione in mundo huis temporis, Evangelii nuntiandi, (8 decembris 1975), nr 73, „Acta Apostolicae Sedis” (odtąd AAS) 68(1976), s. 5-76, tekst polski: „Chrześcijanin w Świecie” 8(1976), s. 20-56, (odtąd: EN); por. J. Fuentes, Comentario al can. 780, w: A. Marzoa, J. Miras, R. Rodríguez-Ocańa (red.), Comentario exegético al Código de Derecho Canónico, t. 3, cz. I, Pamplona 2002³, s. 159-160.

${ }^{2}$ Congregazione per il Clero, Direttorio Generale per la Catechesi (15 agosto 1997), nr 234, Città del Vaticano 1997, tekst polski: Kongregacja ds. Duchowieństwa, Dyrektorium ogólne o katechizacji, Poznań 1998, (odtąd: DOK).
} 
równo w prowadzonym procesie katechetycznym, jak i w rozwoju wiary katechizowanych $^{3}$. Redaktorzy Directorium catechisticum generale z 1971 roku przypominają, że „najszlachetniejsze [...] przymioty ludzkie i chrześcijańskie katechety bardziej gwarantują owocność katechezy aniżeli wyszukane metody"4. Niską jakość ma nauczanie katechetyczne prowadzone przez nieodpowiednio uformowanych i źle przygotowanych katechetów ${ }^{5}$.

Formacja zmierza do uczynienia z katechety wychowawcy człowieka i życia ludzkiego w wierze ${ }^{6}$, troszczy się o uzdolnienie nauczających do przekazywania Ewangelii, osiaga swój szczyt i centrum, gdy zdobywa się odpowiedzialność i zdolność do przekazywania ewangelicznego orędzia ${ }^{7}$. Dodać należy, że formacja do posługi katechetycznej dzieli się na początkową (podstawową) i stałą (permanentną) ${ }^{8}$.

Prawodawcy kościelni, rozumiejąc potrzebę i konieczność odpowiedniego przygotowania katechetów, wielokrotnie zwracają uwagę na odpowiednią formację katechizujących i domagają się jej . Na konieczność przygotowania do posługi w katechezie wskazuje kan. 780 Kodeksu Prawa Kanonicznego, gdzie ustawodawca poleca ordynariuszom miejsca troskę o odpowiednie przygotowanie katechetów do właściwego wypełniania ich zadania ${ }^{10}$, jak również kan. $256 \S 1$,

${ }^{3}$ Por. J. Szpet, Dydaktyka katechezy, Poznań 1999, s. 263.

${ }^{4}$ Directorium Catechisticum Generale (11 aprilis 1971), nr 71, Città del Vaticano 1971, tekst polski „Wiadomości Archidiecezjalne Warszawskie” 63(1973), nr 2, s. 37-112 (odtąd: DCG).

${ }^{5}$ Por. DOK, nr 234; por. A. Urru, La funzione di insegnare della Chiesa. Nella legislazione attuale, Roma 2001, s. 71.

${ }^{6}$ Por. Joannes Paulus P.P. II, Adhortatio Apostolica, Catechesi tradendae (16 octobris 1979), nr 22, AAS 71(1979), 1277-1340, tekst polski: Katecheza po Soborze Watykańskim II w świetle dokumentów Kościoła, W. Kubik (red.), cz. II, Warszawa 1985, s. 146-217, (odtąd: CT).

${ }^{7}$ Por. DOK, nr 235.

${ }^{8}$ Należy „odpowiednio organizować formację katechetów w tym, co dotyczy tak formacji podstawowej, jak i stałej” - DOK, nr 233; „trzeba będzie zwrócić uwagę na formację katechetyczną prezbiterów, tak w planach studiów w formacji seminaryjnej, jak i w okresie formacji stałej" DOK, nr 234; , „biskup powinien także zatroszczyć się [...] na pierwszym miejscu, o właściwą liczbę katechetów wspieranych przez skuteczną strukturę diecezjalną, która zatroszczy się o odpowiednią formację katechetów, zarówno podstawową, jak i permanentną" - Congregaticio pro Episcopis, Direttorio per il ministero pastorale dei vescovi (22 febbraio 2004), nr 128, Città del Vaticano 2004, tekst polski: Kongregacja do spraw Biskupów, Dyrektorium o pasterskiej posłudze biskupów „Apostolorum Successores”, Kielce 2005, (odtąd: AS); por. DOK, nr 11, 247, DCG, nr 110, kan. 780, $228 \S 1,229 \S 2-3,231 \S 1,256 \S 1$.

${ }^{9}$ Katecheta jest to wierny, który w sposób bezpośredni realizuje nauczanie katechetyczne. Każdy wierny może być katechetą w dwu odrębnych formach: jako działający na swoją własną odpowiedzialność albo na podstawie misji do katechizowania, której udziela mu kompetentna władza kościelna. Ten drugi rodzaj katechetów jest właściwy dla katechezy publicznej i urzędowej Kościoła. Przedmiotem rozważań w niniejszym artykule są katecheci urzędowi. Por. J. Fuentes, Comentario al can. 780, dz. cyt., s. 157.

${ }^{10}$ Zob. kan. 773, $775 \S 1$ i 3, 778, $229 \S 1$ i 3; por. J. Fuentes, Comentario al can. 780, dz. cyt., s. 160; por. S. Fundowicz, Obowiazki i uprawnienia wiernych świeckich $w$ realizacji misji 
gdzie zawarto postanowienie: ,należy pilnie pouczać alumnów w tym, co w szczególny sposób jest związane ze świętym posługiwaniem, zwłaszcza w umiejętności katechizowania".

Pośrednio na wspomnianą formację wskazuje kan. $231 \S 1$, w myśl którego „świeccy, którzy na stałe lub czasowo poświęcają się posłudze Kościoła, obowiązani są zdobyć odpowiednią formację potrzebną do właściwego wykonywania swego zadania, by ją spełniali świadomie, umiejętnie i pilnie"11.

O konieczności przygotowania pracowników katechezy stanowiły także schematy do Kodeksu Prawa Kanonicznego. Kanon 32 schematu z 1977 roku zawiera w tej sprawie następujące postanowienie: „ordynariusze miejsca powinni zatroszczyć się o to, ażeby ci, którzy są posyłani do katechizacji otrzymali odpowiednie przygotowanie do podjęcia tego zadania" ${ }^{2}$. Podobnie potrzebę kształcenia katechizujących widzą redaktorzy schematów kodeksu z $1980^{13}$ i $1982 \mathrm{roku}^{14}$.

Także pozakodeksowe normy kanoniczne przypominają obowiązek formacji katechetów. Dyrektorium ogólne o katechizacji zawiera następujące postanowienie: „w celu właściwego funkcjonowania posługi katechetycznej w Kościele partykularnym pierwszorzędne znaczenie nadaje się odpowiedniemu duszpasterstwu katechetów. Trzeba więc starać się, aby: odpowiednio organizować formację katechetów w tym, co dotyczy tak formacji podstawowej, jak i stałej”"15. Również autorzy Directorium catechisticum generale podkreślają konieczność kształcenia katechetów, gdyż same pomoce katechetyczne nie będą skuteczne, o ile będą korzystać z nich katecheci, którzy nie są odpowiednio przygotowani ${ }^{16}$.

Na konieczność formacji głoszących orędzie katechetyczne wskazuje też Dyrektorium o pasterskiej posłudze biskupów w następujących słowach: „,biskup powinien także zatroszczyć się na pierwszym miejscu [o] właściwą liczbę katechetów wspieranych przez skuteczną strukturę diecezjalną, która zatroszczy się o odpowiednią formację katechetów, zarówno podstawową, jak i permanentną, tak by oni sami stali się żywą katechezą"17.

nauczycielskiej Kościoła, w: J. Krukowski, S. Fundowicz, M. Sitarz (red.), Zadanie nauczycielskie Kościoła wobec wyzwań XXI wieku, Radom 2010, s. 105.

${ }^{11}$ Por. A. Urru, La funzione di insegnare, dz. cyt., s. 72.

${ }^{12}$ Pontificia Commissio Codici Iuris Canonici Recognoscendo, Schema canonum libri III De ecclesiae munere docendi, Città del Vaticano 1977, tekst polski: „Posoborowe Prawodawstwo Kościelne" t. 11, z. 1, nr 21077-21259, s. 286-328.

${ }^{13}$ Schema Codicis Iuris Canonici, Città del Vaticano 1980, can. 735.

${ }^{14}$ Codex Iuris Canonici, Schema novissimum iuxta placita Patrum Commissionis emendatum atque Summo Pontifici praesentatum, Città del Vaticano 1982, can. 780.

${ }^{15}$ DOK, nr 233. W nr 223 DOK poleca biskupowi troskę o katechizację i o stosowne przygotowanie katechetów.

${ }^{16}$ Por. DCG, nr 108; por. C. Romero, La catequesis en el Código de Derecho Canónico, „Efemérides Mexicana" 6(1988), nr 17, s. 209.

${ }^{17}$ AS, nr 128. 
Z kolei Dyrektorium o postudze i życiu kapłanów wskazuje, że „prezbiter, jako współpracownik Biskupa i posłany przez niego [...] szczególną troską powinien otoczyć początkową i stałą formację katechetów [...]. W miarę możliwości kapłan powinien być katechetą katechetów, tworząc z nimi prawdziwą wspólnotę uczniów Pana, służącą za punkt odniesienia dla katechizujących"18.

Wreszcie Ratio fundamentalis institutionis sacerdotalis ustala, że „należy też zapewnić alumnom formację ściśle pastoralną, dostosowaną do różnych uwarunkowań regionalnych. [...] Formacja ta winna się odnosić przede wszystkim do umiejętności katechizowania [...]”19, a także ,uwzględniwszy położenie Seminarium, liczbę alumnów i inne okoliczności, należy organizować w ciągu roku szkolnego ćwiczenia, które wtedy wydają się bardziej stosowne, jak: katechizacja $[\ldots]^{\prime 20}$.

\section{Podmioty odpowiedzialne za przygotowanie katechetów}

Według kan. $774 \S 1$ Kodeksu Prawa Kanonicznego wszelkie nauczanie katechetyczne musi dokonywać się pod kierownictwem prawowitej władzy kościelnej. Jest jasne, że także formacja do posługi katechetycznej podlega kompetentnemu autorytetowi kościelnemu. Lecz o kogo chodzi w wyrażeniu „prawowita władza kościelna" z kan. 774 § 1 ? Trzeba stwierdzić, że ową ,prawowitą władzą kościelną” jest Stolica Apostolska na płaszczyźnie międzynarodowej jako najwyższy moderator całej katechizacji w Kościele powszechnym, następnie konferencja biskupów na płaszczyźnie narodowej (krajowej, regionalnej), biskup diecezjalny albo ordynariusz miejsca $\mathrm{w}$ diecezji, proboszcz $\mathrm{w}$ parafii ${ }^{21}$, rektor seminarium duchownego i wykładowcy, zwłaszcza katechetyki, przełożeni zakonni, stowarzyszeń życia apostolskiego oraz instytutów świeckich.

W Kościele powszechnym odpowiedzialność za przygotowanie katechetów ponosi Stolica Apostolska (Stolica Święta), przez którą należy rozumieć „nie tylko Biskupa Rzymskiego, lecz także - o ile nie wynika co innego z natury rzeczy lub z kontekstu - Sekretariat Stanu, Radę Publicznych Spraw Kościoła, jak również inne instytucje Kurii Rzymskiej"22. Na mocy motu proprio Fides per doctri-

\footnotetext{
${ }^{18}$ Congregatio pro Clericis, Direttorio per il ministero e la vita dei Presbiteri "Tota Ecclesia" (31 gennaio 1994), nr 47, Città del Vaticano, 1994, tekst polski: Kongregacja ds. Duchowieństwa, Dyrektorium o posłudze i życiu kapłanów, Città del Vaticano 1994.

${ }^{19}$ Sacra Congregazione per L'educazione Cattolica, Ratio fundamentalis institutionis sacerdotalis (6 ianuarii 1970 r.), AAS (1970), s. 321-384, editio apparata post Codicem iuris canonici promulgatum (19 marzo 1985), nr 94, Città del Vaticano 1985, (odtąd: Ratio fundamentalis).

${ }^{20}$ Tamże, nr 98.

${ }^{21}$ Por. C. Romero, La catequesis, dz. cyt., s. 210.

${ }^{22}$ Kan. 361.
} 
nam z 16 stycznia 2013 roku ${ }^{23}$ papieża Benedykta XVI sprawy związane z katechezą, a więc i kwestia formacji katechetów, zostały podporządkowane nowej dykasterii Kurii Rzymskiej utworzonej 21 września 2010 roku, mianowicie Papieskiej Radzie ds. Nowej Ewangelizacji (łac. Pontificium Consilium de Nova Evangelizatione Promovenda) ${ }^{24}$.

Kanon $775 \S 1$ odnosi się do przepisów tyczących się katechezy wydawanych przez Stolicę Apostolską, których ma przestrzegać biskup diecezjalny ${ }^{25}$. Takie normy dotyczące formacji katechetów znajdują się przede wszystkim w Direttorio Generale per la Catechesi w numerach 233-252 ${ }^{26}$. Przepisy odnoszące się do przygotowania katechetów znajdują się także w Directorium catechisticum generale w nr. 108-115.

Kolejnym podmiotem odpowiedzialnym za przygotowanie katechetów, lecz na płaszczyźnie krajowej (narodowej, regionalnej), jest konferencja biskupów. Kanon $775 \S 3$ postanawia, że ,przy Konferencji Episkopatu można powołać urząd katechetyczny, którego głównym zadaniem byłoby świadczenie pomocy poszczególnym diecezjom w sprawach katechezy”"27. Z pewnością w ramach „,pomocy poszczególnym diecezjom w sprawach katechezy" będzie się mieściła kwestia przygotowania katechizujących ${ }^{28}$.

Referat katechetyczny lub Ośrodek Krajowy ds. Katechezy przy Konferencji Episkopatu pełni dwie funkcje: służy potrzebom katechetycznym, które dotyczą wszystkich

${ }^{23}$ Opublikowanym w wydaniu codziennym „L'Osservatore Romano” z dnia 26 stycznia 2013 r.

${ }^{24}$ Dotychczas sprawy związane z katechezą należały do kompetencji Kongregacji ds. Duchowieństwa. Według konstytucji apostolskiej Pastor Bonus wymieniona Kongregacja miała czuwać nad właściwą realizacją formacji katechetycznej. Joannes Paulus P.P. II, Constitutio Apostolica Pastor Bonus, (28 iulii 1988), art. 94, AAS 80 (1988), s. 841-912. Direttorio Generale per la Catechesi przypomina, że Kongregacja ds. Duchowieństwa „czuwa, aby formacja katechetyczna była prowadzona w poprawny sposób" - DOK, nr 271; por. DCG, nr 134; por. C. Romero, La catequesis, dz. cyt., s. 211.

${ }^{25}$ „Na biskupie ciąży odpowiedzialność za kształtowanie katechezy diecezjalnej, według norm i zasad wydanych przez Stolicę Apostolską" - AS, nr 128.

${ }^{26} \mathrm{~W}$ Dyrektorium o postudze i życiu kapłanów (dokumencie wydanym przez Kongregację ds. Duchowieństwa), czytamy, że „prezbiter [...] szczególną troską powinien otoczyć początkową i stałą formację katechetów" - Congregatio pro Clericis, Direttorio per il ministero e la vita dei Presbiteri "Tota Ecclesia", dz. cyt., nr 47.

${ }^{27}$ Urząd katechetyczny, który można utworzyć w łonie konferencji biskupiej, jest nieobowiązkowy, to znaczy może, lecz nie musi być utworzony, i jeśli się go powoła do istnienia, to jego misją jest jedynie pomoc biskupom diecezjalnym w trosce o katechizację. Por. C. Romero, La catequesis, dz. cyt., s. 211; zob. J. Krukowski, Kompetencje konferencji biskupów w zakresie realizacji zadania nauczycielskiego Kościoła, w: Zadanie nauczycielskie Kościoła..., dz. cyt., Radom 2010, s. 58.

${ }^{28}$ W schemacie ks. III KPK z 1977 widniał następujący zapis: „Zachowując normy wydane przez Stolicę Apostolską jak również uzgadniając z nią swoje propozycje, Konferencje biskupów winny wydać dla własnego terytorium normy dotyczące katechizacji” - Schema canonum libri III De ecclesiae munere docendi $\mathrm{z} 1977$, can. 26. Zapis ten nie pojawia się jednak w schematach z 1980 r. (zob. can. 730 § 2-3) i z 1982 r. (can. 775 § 2-3). 
diecezji danego terytorium. Zajmuje się publikacjami, które mają zasięg narodowy, kongresami narodowymi, współpracą ze środkami społecznego przekazu i w ogóle wszystkimi pracami oraz zadaniami, które przekraczają możliwości poszczególnych diecezji lub regionu

oraz ,służy diecezjom i regionom w rozpowszechnianiu informacji i programów katechetycznych, aby koordynować działanie i pomagać diecezjom mniej rozwiniętym w dziedzinie katechezy"29. Choć cytowany passus Direttorio generale per la catechesi nie mówi wyraźnie o formacji katechetów, to nie ulega wątpliwości, że w stwierdzeniu, iż „Referat katechetyczny lub Ośrodek Krajowy ds. Katechezy przy Konferencji Episkopatu służy potrzebom katechetycznym, które dotyczą wszystkich diecezji danego terytorium", mieści się także w określonym zakresie przygotowanie katechetów. Natomiast wyraźnie o konferencji biskupów w sprawie kształcenia katechetów wspomina Directorium Catechisticum Generale w następującym postanowieniu:

na pierwszym miejscu należy się zatroszczyć o formację tych, którzy prowadzą działalność katechetyczną obejmującą swym zasięgiem cały kraj. Troska o te sprawy spoczywa na Konferencjach Biskupich. Jednakże formacja osób kierujących poczynaniami katechetycznymi w skali krajowej powinna się z kolei przedłużać w formacji osób prowadzących działalność katechetyczną na terenie regionu i diecezji. Owszem, ma być jakby jej naturalnym uzupełnieniem i kontynuacją. To drugie zadanie należy do Konferencji Biskupich regionalnych, gdy takie istnieją lub do poszczególnych biskupów ${ }^{30}$.

Trzeba dodać, że w myśl kan. 774 § 1 konferencja biskupów jest niewątpliwie ową prawowitą władzą kościelną kierującą katecheza, w tym także przygotowaniem do pracy w katechezie. Oczywiście konferencja biskupów pełni jedynie funkcję pomocniczą odnośnie do kształcenia katechetów, ponieważ zasadniczo odpowiedzialność za tę kwestię w diecezji spada na biskupa diecezjalnego ${ }^{31}$.

Najważniejszym podmiotem odpowiedzialnym za przygotowanie do pracy w katechezie jest biskup diecezjalny i zrównani z nim w prawie ${ }^{32}$. „Biskup diecezjalny powinien troszczyć się o to, by pilnie wypełniano przepisy kanonów, dotyczące posługi słowa, zwłaszcza [...] nauczania katechetycznego"33. Prawodawca kodeksowy wyraźnie zobowiązuje ordynariuszy miejsca do troski o odpowiednie przygotowanie katechetów do właściwego wypełniania ich zadania i podkreśla znaczenie tej powinności ordynariuszy ${ }^{34}$. Warto dodać, że pod nazwą

${ }^{29}$ DOK, nr 269.

${ }^{30}$ DCG, nr 108; por. tamże, nr 109.

${ }^{31}$ Por. tamże, nr 108.

${ }^{32}$ Por. kan. 368; por. Z. Grocholewski, „Munus docendi” biskupa, „Prawo - Administracja Kościół" 5(2001), nr 1, s. 24.

${ }^{33}$ Kan. 386 § 1; por. C. Romero, La catequesis, dz. cyt., s. 212.

${ }^{34}$ Por. kan. 780. 
ordynariusz miejsca rozumiani są w prawie, oprócz biskupa rzymskiego, biskupi diecezjalni oraz inni, którzy - choćby tylko czasowo - są przełożonymi Kościoła partykularnego lub wspólnoty do niego przyrównanej zgodnie z przepisem kan. 368, jak również ci, którzy w nich mają ogólną wykonawczą władzę zwyczajną, mianowicie wikariusze generalni i biskupi ${ }^{35}$.

Pośrednio o odpowiedzialności biskupa diecezjalnego i innych ordynariuszy miejsca dotyczącej omawianej kwestii stanowi kan. 773, w myśl którego „własnym i poważnym obowiązkiem, zwłaszcza duszpasterzy, jest troska o katechizację ludu chrześcijańskiego"36. To właśnie wspomniani hierarchowie są w sensie ścisłym duszpasterzami, którzy winni troszczyć się o kształcenie katechizujących.

Direttorio per il ministero pastorale dei vescovi mówi expressis verbis, że „głównym zadaniem biskupa, obok nauczania, jest promowanie żywej i efektywnej katechezy. Biskup powinien także zatroszczyć się [...] na pierwszym miejscu [o] właściwą liczbę katechetów wspieranych przez skuteczną strukturę diecezjalną, która zatroszczy się o odpowiednią formację katechetów, zarówno podstawową, jak i permanentną" 37 .

$\mathrm{Na}$ pierwszorzędną rolę biskupa diecezjalnego w kształceniu katechetów wskazuje następująca dyspozycja Direttorio generale per la catechesi:

troska o katechizację powinna prowadzić biskupa do podjęcia „najwyższego kierownictwa katechizacji w Kościele partykularnym", co zakłada między innymi: [...] zatroszczyć się o stosowne przygotowanie katechetów do ich zadań, tak żeby mieli dokładną znajomość nauki Kościoła oraz zasad psychologii, a wiedzę pedagogiczną, aby opanowali teoretycznie i praktycznie ${ }^{38}$.

W sposób szczególny biskup winien troszczyć się o formację katechetyczną poprzez utworzenie w diecezji wydziału katechetycznego, którego istnienie jest obowiązkowe. Na ten temat mówi Directorium catechisticum generale:

Dekretem Provido sane został ustanowiony diecezjalny Referat Katechetyczny, którego zadaniem jest kierowanie całą działalnością katechetyczną. Tego rodzaju Referat diecezjalny winien obejmować zespół osób, posiadających właściwą kompetencję. Zakres i różnorodność problemów, nad którymi trzeba się zastanawiać, domaga się rozłożenia odpowiedzialności na wiele osób naprawdę biegłych. Referat Katechetyczny Kurii Diecezjalnej jest narzędziem, którym posługuje się biskup [...] głowa wspólnoty i wykładowca nauki dla kierowania całą działalnością katechetyczną w diecezji. Każda diecezja musi posiadać własny Referat Katechetyczny ${ }^{39}$.

${ }^{35}$ Kan. $134 \S 1-2$; por. C. Romero, La catequesis, dz. cyt., s. 211.

${ }^{36}$ Zob. kan. 774 § 1.

${ }^{37}$ AS, nr 128; zob. Z. Grocholewski, „Munus docendi” biskupa, dz. cyt., s. 22.

${ }^{38}$ DOK, nr 223

${ }^{39}$ DCG, nr 126; zob. Sacra Congregatio Concilii, Decretum Provido sane consilio (12 ianuarii 1935), III, nr 1, s. 151, AAS 27(1935), s. 145-154; DOK, nr 265, przypis 1; por. C. Romero, La catequesis, dz. cyt., s. 212. 
Natomiast Direttorio generale per la catechesi wyraźnie przypomina, że „do najważniejszych zadań diecezjalnego Referatu katechetycznego należy: [...] pomoc katechetom i ich formowanie. W tym celu należy założyć ośrodki, które uważa się za bardziej odpowiednie ${ }^{40}$. [...] Każda diecezja musi posiadać własny Referat katechetyczny" ${ }^{\prime 1}$.

Wreszcie w określonym zakresie odpowiedzialność za formację do nauczania katechetycznego ponosi proboszcz - ,wychowawca w wierze"42. Jest on bowiem pierwszym odpowiedzialnym za głoszenie słowa Bożego w parafii i obowiązany jest troszczyć się o to, ażeby przebywającym w parafii głoszone było nieskażone słowo Boże, zabiegając o to, by wierni byli właściwie o prawdach wiary pouczeni, zwłaszcza przez m.in. nauczanie katechetyczne ${ }^{43}$.

Według Dyrektorium ogólnego o katechizacji „prezbiter, a w szczególności proboszcz, ma następujące zadania w dziedzinie katechezy: [...] wzbudzać powołania do posługi katechetycznej i jako katecheta katechetów troszczyć się o ich formację, poświęcając temu zadaniu najwyższą uwage" ${ }^{44}$. Natomiast redaktorzy Ogólnej instrukcji katechetycznej przypominaja, że „duchowieństwo, jak również ci wszyscy, którzy są odpowiedzialni za kierowanie działalnością katechetyczną, mają obowiązek troszczyć się o stałą formację swoich współpracowników w katechizowaniu"45, co odnosi się do proboszcza i innych prezbiterów.

Przede wszystkim alumni seminarium duchownego muszą stopniowo angażować się w katechizację, mając świadomość, że będzie ona w przyszłości jedną $\mathrm{z}$ ich istotnych trosk duszpasterskich. Ta kwestia jest uregulowana w kan. 256 $\S 1$, gdzie prawodawca postanawia: ,należy pilnie pouczać alumnów w tym, co w szczególny sposób jest związane ze świętym posługiwaniem, zwłaszcza w umiejętności katechizowania [...]", jak również w Ratio fundamentalis institutionis sacerdotalis, gdzie znajduje się następująca dyspozycja: „należy też zapewnić alumnom formację ściśle pastoralną, dostosowaną do różnych uwarunkowań regionalnych. [...] Formacja ta winna się odnosić przede wszystkim do umiejętności katechizowania [...]"46, a także w Directorium catechisticum generale: ,jest rzeczą wielkiej wagi przekazywanie alumnom w seminariach i szkołach solidnego przygotowania katechetycznego oraz doskonalenia go później przez wspomnianą poprzednio stałą formację" ${ }^{" 47}$. Stąd poważna odpowiedzialność

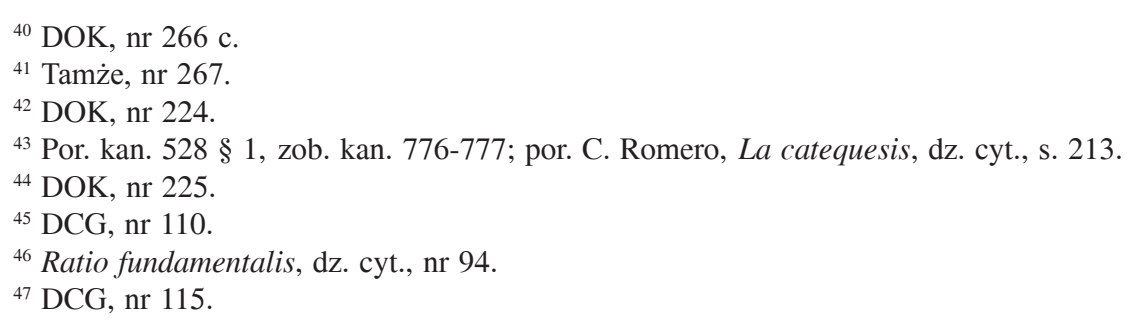


za przygotowanie do katechizowania przyszłych prezbiterów spada na rektora seminarium duchownego i wykładowców, zwłaszcza katechetyki ${ }^{48}$.

Odpowiedzialni za formację katechetyczną są także przełożeni zakonni, stowarzyszeń życia apostolskiego oraz instytutów świeckich, których członkowie uczestniczyć będą w posłudze katechetycznej lub już ją realizują ${ }^{49}$.

\section{Charakter i treść formacji katechetów}

Celem formacji jest uczynienie katechetów zdolnymi do przekazywania Ewangelii tym, którzy pragną powierzyć się Jezusowi Chrystusowi, zdobycie odpowiedzialności i zdolności do przekazywania orędzia ewangelicznego ${ }^{50}$. Jak wspomniano wyżej, przygotowanie do posługi katechetycznej obejmuje zarówno formację podstawowa, jak i stałą ${ }^{51}$. Tak więc $\mathrm{z}$ prawem i obowiązkiem katechetów do formacji1 ${ }^{52}$ łączy się obowiązek zapewnienia im ze strony kompetentnej władzy kościelnej adekwatnego przygotowania początkowego oraz permanentnego.

Formacja podstawowa ma za cel uczynić przyszłych katechetów zdolnymi do dobrego wykonywania ich zadania. To wymaga, aby przyswoili sobie oni doktrynę kościelną w sposób przystosowany do środowiska i kultury wiernych ${ }^{53}$, którym będą przekazywać katechezę, oraz poznali teorię i praktykę pedagogiczną ${ }^{54}$. Stąd prawodawca w kan. 780 nie tylko domaga się wykształcenia w doktrynie, lecz w sposób ogólny wspomina także o formacji w „dyscyplinach pedagogicznych" 55 .

Autorzy Dyrektorium ogólnego o katechizacji dokładniej eksplikują wymiary formacji katechetów. Tak więc winna być to formacja ludzka, chrześcijańska

48 „Oprócz formacji tych, którzy będą podejmować zadania kierownicze w katechezie, instytuty te powinny przygotowywać nauczycieli katechetyki dla seminariów [...]”- DOK, nr 251.

${ }^{49}$ Zob. kan. 660, 713, $731 \S 1,735-736$. „Oprócz formacji tych, którzy będą podejmować zadania kierownicze w katechezie, instytuty te [ośrodki dla specjalistów w dziedzinie katechezy] powinny przygotowywać nauczycieli katechetyki dla [...] domów formacyjnych [...]" - DOK, nr 251.

${ }^{50}$ Por. DOK, nr 235.

${ }^{51}$ Por. tamże, nr 233.

${ }_{52}$ Por. kan. $231 \S 1$.

53 „Chodzi przede wszystkim o formację katechetów dla potrzeb ewangelizacyjnych obecnej chwili historycznej, z jej wartościami, wyzwaniami i cieniami" - DOK, nr 237; zob. C. Romero, La catequesis, dz. cyt., s. 210.

54 „Uwzględniwszy położenie Seminarium, liczbę alumnów i inne okoliczności, należy organizować w ciagu roku szkolnego ćwiczenia, które wtedy wydają się bardziej stosowne, jak: katechizacja [...]" - Ratio fundamentalis, dz. cyt., nr 98.

${ }^{55}$ Por. J. Fuentes, Comentario al can. 780 , dz. cyt., s. 160; por. A. Urru, La funzione di insegnare, dz. cyt., s. 72 . 
i apostolska ${ }^{56}$, biblijno-teologiczna ${ }^{57}$, w zakresie nauk humanistycznych (psychologii, nauk społecznych, nauk dotyczących wychowania i komunikacji $)^{58}$ oraz pedagogiczna ${ }^{59}$.

Schemat księgi III z 1977 roku zawierał w tej sprawie postanowienie: „ordynariusze miejsca powinni zatroszczyć się o to, ażeby ci którzy są posyłani do katechizacji otrzymali odpowiednie przygotowanie do podjęcia tego zadania. Chodzi mianowicie o przyswojenie sobie odpowiedniej znajomości nauki Kościoła, jak również zasad wiedzy psychologicznej i pedagogicznej zarówno teoretycznie, jak i praktycznie" ${ }^{\circ 0}$. Natomiast redaktorzy Directorium catechisticum generale mówią o formacji teologiczno-doktrynalnej, antropologicznej i metodologicznej ${ }^{61}$.

Kanon 780 postanawia, że odpowiednie przygotowanie katechetów do właściwego wypełniania ich zadania winno mieć charakter stały. Formacja permanentna musi więc umożliwiać ustawiczne dokształcanie mające na celu pogłębianie zagadnień kulturalnych, metod nauczania, umiejętności stosowania narzędzi (pomocy) oferowanych przez technikę, jak również winna tak wzbogacać katechetów duchowo, aby wraz z nauczaniem teoretycznym mogli ofiarować także „świadectwo wiary, które winno łączyć autentyczny przykład życia chrześcijańskiego i zdolność do ofiary" 62 .

${ }^{56}$ Por. DOK, nr 239. „Zadanie powierzone katechecie domaga się od niego intensywnego życia sakramentalnego i duchowego, praktyki modlitwy, głębokiego zrozumienia wzniosłości chrześcijańskiego orędzia i jego skuteczności w przemianie życia, gorliwej miłości, pokory i roztropności, które pozwalają na owocne działanie Ducha Świętego w osobach katechizowanych" - DCG, nr 114.

57 „Formacja biblijno-teologiczna dostarczy mu organicznej znajomości orędzia chrześcijańskiego skupionego wokół centralnego misterium wiary, którym jest Jezus Chrystus" - DOK, nr 240.

${ }_{58}$ „Katecheta dochodzi do poznania człowieka i rzeczywistości, w jakiej żyje, także za pośrednictwem nauk humanistycznych, które osiagnęły w naszych czasach wyjątkowy stopień rozwoju” - DOK, nr 242. „W parze jednak z tym wykształceniem [formacją ściśle pastoralna] niech alumni starają się osiaggnąć tę umiejętność, aby potrafili być obecni w życiu wiernych ze szczególną wrażliwością i usposobieniem pasterskim. Do pełniejszego poznania ludzi i rzeczywistości niemało mogą im pomóc dyscypliny psychologiczne, pedagogiczne i socjologiczne, których jednak należy uczyć stosownymi metodami i według zasad ustalonych przez Władzę kościelną" - Ratio fundamentalis, dz. cyt., nr 94; zob. Z. Grocholewski, ,Munus docendi” biskupa, dz. cyt., s. 25.

59 „Katecheta jest wychowawca, który ułatwia dojrzewanie wiary, jakie katechumen lub katechizowany realizuje z pomocą Ducha Świętego”- DOK, nr 244. „Formacja metodologiczna. Zgodnie ze swoim założeniem metodologia pilnie rozważa środki potwierdzone doświadczeniem. $Z$ tej racji należy położyć większy nacisk bardziej na ćwiczenia praktyczne niż na dokształcenie teoretyczne w zakresie pedagogii. Jednakże mimo wszystko konieczna jest również formacja teoretyczna dla udzielania katechecie pomocy, by spotkał się odpowiednio z różnymi sytuacjami, dla uniknięcia formy empirycznej w przekazywaniu katechezy, dla zrozumienia zmian, jakie zachodzą w zakresie wychowania, dla odpowiedniego pokierowania przyszłą pracą" - DCG, nr 112 c.

${ }^{60}$ Schema canonum libri III De ecclesiae munere docendi z 1977, dz. cyt., can. 32.

${ }^{61}$ DCG, nr 112.

${ }^{62}$ DCG, nr 35; por. A. Urru, La funzione di insegnare, dz. cyt., s. 72; por. J. Fuentes, Comen- 
Pośrednio permanentną formację katechetyczną księży porusza kan. 279 § 1: duchowni również po przyjęciu kapłaństwa powinni kontynuować studia teologiczne. Niech się starają postępować za tą solidną doktryną, opartą na Piśmie świętym, przekazaną przez przodków i powszechnie przyjętą przez Kościół, która jest określona zwłaszcza w dokumentach Soborów i Biskupów Rzymskich, unikając świeckich nowości oraz fałszywej wiedzy ${ }^{63}$.

\section{Z kolei Ogólna instrukcja katechetyczna przypomina, że}

formacja stała obejmuje różne sposoby i stopnie. Jest rzeczą konieczną, by była kontynuowana przez cały okres, w którym katecheci pełnią swoje funkcje. Dotyczy zaś ona zarówno tych, którzy kierują działalnością katechetyczną, jak i zwykłych katechetów. Stała formacja nie może być przekazana w sposób wyłączny organom centralnym, lecz troskę o nią winny wykazać także mniejsze wspólnoty chrześcijańskie, również i z tej racji, że warunki oraz potrzeby w zakresie katechezy mogą się różnić w zależności od różnych terytoriów. Duchowieństwo, jak również ci wszyscy, którzy są odpowiedzialni za kierowanie działalnością katechetyczną, mają obowiązek troszczyć się o stałą formację swoich współpracowników w katechizowaniu ${ }^{64}$.

\section{Szkoły dla katechetów}

Biskup diecezjalny (i inni ordynariusze miejsca) winien się zatroszczyć także o odpowiednie szkoły dla katechetów ${ }^{65}$. Wspomniane szkoły mają na celu realizację organicznej i systematycznej formacji katechetycznej o charakterze podstawowym i fundamentalnym. W wystarczająco długim czasie podejmuje się w nich najbardziej specyficzne wymiary katechetyczne formacji: orędzie chrześcijańskie, znajomość człowieka i kontekstu społeczno-kulturowego oraz pedagogię wiary ${ }^{66}$.

W przypadku prezbiterów będzie to zasadniczo wyższe seminarium duchow$n \mathrm{e}^{67}$. O prowadzeniu przygotowania katechetycznego $\mathrm{w}$ wyższym seminarium duchownym postanawia prawodawca w kan. $256 \S 1$, zgodnie z którym: „należy pilnie pouczać alumnów w tym, co w szczególny sposób jest związane ze świę-

tario al can. 780, dz. cyt., s. 160; por. J. Tobin, The diocesan Bishop a Catechist, „Studia Canonica" 18(1984), nr 2, s. 406.

${ }^{63}$ Kan. $279 \S 1$.

${ }^{64}$ DCG, $\mathrm{nr} 110$

${ }^{65}$ DCG, nr 126; por. A. Urru, La funzione di insegnare della Chiesa, dz. cyt., s. 66; por. J. Tobin, The diocesan Bishop a Catechist, dz. cyt., s. 408.

${ }^{66}$ Por. DOK, nr 249.

${ }^{67}$ „Młodzieńcy, zamierzający dojść do kapłaństwa, powinni dla otrzymania odpowiedniej formacji duchowej oraz przygotowania się do właściwych im obowiązków kształcić się w wyższym seminarium przez cały okres formacji, albo - gdy zdaniem biskupa diecezjalnego wymagają tego okoliczności - przynajmniej przez cztery lata” - Kan. $235 \S 1$. 
tym posługiwaniem, zwłaszcza w umiejętności katechizowania [...]"68, jak również Ratio fundamentalis institutionis sacerdotalis: „należy też zapewnić alumnom formację ściśle pastoralną. [...] Formacja ta winna się odnosić przede wszystkim do umiejętności katechizowania [...]"69.

Gdy chodzi o pozostałych katechetów, to będą to różnego rodzaju szkoły: „uczęszczanie do szkoły dla katechetów jest szczególnie ważnym elementem W procesie formacyjnym katechety. W wielu miejscach takie szkoły"70, wyższe instytuty duszpasterstwa katechetycznego oraz szkoły katechetyczne w granicach poszczególnych diecezji ${ }^{71}$, a także uniwersytety katolickie ${ }^{72}$ oraz inne instytuty wyższych studiów ${ }^{73}$, jak również uniwersytety i fakultety kościelne ${ }^{74}$, mają dwa poziomy: dla zwykłych katechetów i dla odpowiedzialnych za katechezę. Niektóre w wymienionych szkół biskup będzie zakładał w diecezji, do innych (ponaddiecezjalnych) będzie starał się kierować kandydatów na katechetów.

\section{Uwagi końcowe}

Na podstawie analizy przepisów prawa kodeksowego i przepisów pozakodeksowych dotyczących formacji do posługi katechetycznej należy stwierdzić, że:

1. Każdy system pedagogiczny do dobrego kształcenia i wychowania wymaga dobrego nauczyciela-wychowawcy. Podobną rolę przypisuje się katechecie zarówno w prowadzonym procesie katechetycznym, jak i w rozwoju wiary katechizowanych.

2. Istnieje potrzeba i konieczność odpowiedniego przygotowania katechetów do wypełniania ich zadania, co znajduje odzwierciedlenie w normach kanonicznych.

3. Formacja do posługi katechetycznej dzieli się na początkową (podstawowa) i stałą (permanentną).

4. Według kan. $774 \S 1$ wszelkie nauczanie katechetyczne musi dokonywać się pod kierownictwem prawowitej władzy kościelnej, dotyczy to także formacji do posługi katechetycznej.

5. Podmiotami odpowiedzialnymi za przygotowanie katechetów do ich posługi są: Stolica Apostolska na płaszczyźnie międzynarodowej jako naj-

\footnotetext{
${ }^{68}$ Por. C. Romero, La catequesis, dz. cyt., s. 213.

${ }^{69}$ Ratio fundamentalis, $\mathrm{nr} 94$.

${ }^{70} \mathrm{DOK}, \mathrm{nr} 248$.

${ }^{71}$ DCG, $\mathrm{nr} 109$.

${ }^{72}$ Kan. 807, 809.

${ }^{73}$ Kan. 814.

${ }^{74}$ Kan. 815-816.
} 
wyższy moderator całej katechizacji w Kościele powszechnym, konferencja biskupów na płaszczyźnie narodowej (krajowej, regionalnej), biskup diecezjalny albo ordynariusz miejsca w diecezji, proboszcz w parafii, rektor seminarium duchownego i wykładowcy, zwłaszcza katechetyki, przełożeni zakonni, stowarzyszeń życia apostolskiego oraz instytutów świeckich.

6. Przygotowanie do posługi katechetycznej (początkowej i permanentnej) winno obejmować formację ludzka, chrześcijańską i apostolską, biblijno-teologiczna, w zakresie nauk humanistycznych (psychologii, nauk społecznych, nauk dotyczących wychowania i komunikacji) oraz pedagogiczną.

7. Kształcenie katechetów winno odbywać się w specjalnych szkołach mających na celu realizację organicznej i systematycznej formacji katechetycznej o charakterze podstawowym i fundamentalnym. W wystarczająco długim czasie podejmuje się w nich najbardziej specyficzne wymiary katechetyczne formacji: orędzie chrześcijańskie, znajomość człowieka i kontekstu społeczno-kulturowego oraz pedagogię wiary.

8. Szkoły przygotowujące do pracy w katechizacji winny mieć dwa poziomy: dla „zwykłych katechetów” i dla „odpowiedzialnych za katechezę”.

\section{Formation of Catechists in the Canonic Aspect}

\section{Summary}

The article first presents the need and necessity of the formation of catechists. Then it shows the issue of the subject responsible for the preparation of catechists. There is also a lengthy discussion of the character and contents of instruction offered to catechists, both in the basic and the ongoing formation. The last paragraph is devoted to schools for catechists.

\section{Keywords}

formation, catechist, bishop, Holy See, Conference of Bishops

\section{Slowa kluczowe}

formacja, katecheta, biskup, Stolica Apostolska, Konferencja Biskupów 